\title{
Gambaran persalinan letak sungsang di RSUP Prof. Dr. R. D. Kandou Manado
}

\author{
${ }^{1}$ Bonatua A. Putra \\ ${ }^{2}$ Eddy Suparman \\ ${ }^{2}$ Hermie M. M. Tendean
}

\author{
${ }^{1}$ Kandidat Skripsi Fakultas Kedokteran Universitas Sam Ratulangi Manado \\ ${ }^{2}$ Bagian Obstetri dan Ginekologi Kedokteran Universitas Sam Ratulangi Manado \\ Email: Bonatuaarieputra@gmail.com
}

\begin{abstract}
Breech presentation is lengthwise position of fetus in the womb with its head is in the fundus. Causes of breech presentation are unknown, however, there are some risk factors, among others: uterine abnormality, gemelli, easily movable fetus (in multiparous, hidramnion, premature), and head fixation on the pelvic brim is not good enough or no fixation at all (in narrow pelvis, hydrocephalus, or anencephaly cases). This study aimed to obtain the profile of breech delivery. This was a descriptive retrospective study using medical records at Prof. Dr. R. D. Kandou Hospital Manado period January-December 2014. The results showed that of the total 3347 labors, there were 152 cases of breech delivery (2.2\%). The highest percentages were as follows: multiparous mothers (64.5\%); maternal age >35 years (28.9\%); 37-40 weeks of gestation (78.3\%); complete breech (66.4\%); and perabdominal labor (78.3\%). Birth weights were mostly in the range of 2500-3500 grams (65.1\%) with Apgar scores 4-6 (61.2\%). Keywords: breech delivery.
\end{abstract}

\begin{abstract}
Abstrak: Letak sungsang adalah janin yang letaknya memanjang (membujur) dalam rahim, kepala berada di fundus dan bokong di bawah. Penyebab terjadinya letak sungsang tidak diketahui, tetapi terdapat beberapa faktor risiko antara lain: kelainan uterus, gemeli, janin mudah bergerak (pada multipara, hidramnion, prematur), dan fiksasi kepala pada pintu atas panggul tidak baik atau tidak ada (pada panggul sempit, hidrosefalus, anensefali). Penelitian ni bertujuan untuk mendapatkan gambaran persalinan letak sungsang. Jenis penelitian ialah retrospektif deskriptif melalui rekam medik di RSUP Prof. Dr. R. D. Kandou Manado periode Januari - Desember 2014. Hasil penelitian mendapatkan 152 kasus persalinan letak sungsang yaitu sebesar 2,2\% dari total 3347 persalinan. Persentase tertinggi ditemukan pada ibu multipara (64,5\%); usia ibu >35 tahun (28,9\%); usia kehamilan 37-40 minggu (78,3\%); complete breech $(66,4 \%)$; persalinan perabdominal $(78,3 \%)$. Berat badan lahir bayi letak sungsang terbanyak pada rentang $2500-3500 \mathrm{~g}(65,1 \%)$ dengan nilai apgar terbanyak pada nilai 4-6 (61,2\%).
\end{abstract}

Kata kunci: persalinan letak sungsang

Letak sungsang adalah janin yang letaknya memanjang (membujur) dalam rahim dengan kepala berada di fundus dan bokong di bawah. ${ }^{1}$ Persalinan pada bayi dengan presentasi sungsang dimana bayi letaknya sesuai dengan sumbu badan ibu, kepala berada pada fundus uteri sedangkan bokong merupakan bagian terbawah atau di bagian pintu atas panggul. ${ }^{2}$ Pada letak sungsang berturut-turut lahir bagian-bagian yang makin lama makin besar,dimulai dari lahirnya bokong, bahu kemudian kepala. ${ }^{3}$ Pada kehamilan belum cukup bulan, frekuensi letak sungsang lebih tinggi, sedangkan pada kehamilan cukup bulan, sebagian besar janin ditemukan dalam 
presentasi kepala. ${ }^{4}$ Pada presentasi bokong, baik ibu dan janin mengalami peningkatan risiko yang besar dibandingkan dengan presentasi kepala. ${ }^{5}$ Persalinan letak sungsang dengan prematuritas memiliki morbiditas dan mortalitas lebih tinggi. ${ }^{6}$

Kehamilan sungsang dapat disebabkan oleh banyak hal, antara lain: kelahiran kembar, cairan amniotik berlebihan, hidrosefalus, anensefali, tali pusat pendek dan kelainan rahim. ${ }^{7}$

Indonesia sampai saat ini merupakan negara dengan angka kematian ibu (AKI) paling tinggi di Asia. Pada penduduk Indonesia tahun 2011 tercatat AKI masih sebesar 228/100.000 kelahiran hidup sdedangkan angka kematian bayi (AKB) usia $0-11$ bulan ialah 34 per 1.000 kelahiran hidup. Target nasional pada tahun 2015 AKI akan turun menjadi 23/100.000 kelahiran hidup. ${ }^{8}$

Pada ibu jarang dijumpai komplikasi yang berkelanjutan, tetapi pada bayi kemungkinan terdapat sisa (komplikasi) dalam bentuk deformitas, gangguan fungsi saraf, dan menurunnya intelgensia. ${ }^{6,19}$

Angka kematian bayi pada persalinan letak sungsang lebih tinggi bila dibandingkan dengan letak kepala. Sebab kematian perinatal yang terpenting akibat terjepitnya tali pusat antara kepala dan panggul pada waktu kepala memasuki rongga panggul serta akibat retraksi uterus yang dapat menyebabkan lepasnya plasenta sebelum kepala lahir. ${ }^{10}$ Selain itu, angka kesakitan pada bayi juga tinggi karena mungkin terjadi fraktur humerus atau klavikula pada waktu melahirkan lengan, serta paralisis lengan karena tekanan atau tarikan pada pleksus brakialis. ${ }^{11}$

Seksio sesarea bisa dipertimbangkan pada keadaan ibu yang primi tua, riwayat persalinan jelek, riwayat kematian perinatal, ada indikasi janin untuk mengakhiri persalinan, kontraksi uterus tidak adekuat, ingin steril, dan bekas seksio sesarea. $^{12}$

\section{METODE PENELITIAN}

Jenis penelitian ini ialah deskriptif retrospektif. Penelitian ini dilakukan di bagian Obstetri Ginekologi RSUP Prof Dr. R. D. Kandou Manado pada bulan November-Desember 2014 dengan menggunakan catatan rekam medis pasien.

Sampel penelitian ini ialah seluruh pasien yang melahirkan di bagian Obstetri Ginekologi di RSUP Prof. Dr. R. D. Kandou Manado periode Januari-Desember 2014. Kriteria inklusi ialah ibu hamil dengan janin letak sungsang dan mempunyai data rekam medis lengkap di RSUP Prof. Dr. R. D. Kandou Manado. Kriteria eksklusi ialah data rekam medis yang tidak lengkap.

Data rekam medis meliputi paritas, usia ibu, usia kehamilan, jenis presentasi, jenis persalinan, skor apgar, serta berat badan lahir. Data yang diperoleh disajikan dalam bentuk tabel distribusi.

\section{HASIL PENELITIAN}

Persalinan letak sungsang di RSUP periode Januari 2014 - Desember 2014 berjumlah 152 kasus dari total 3347 persalinan yaitu sebanyak 2,2\% di RSUP Prof. Dr. R. D. Kandou Manado.

Tabel 1 menunjukkan bahwa kelompok pasien persalinan letak sungsang terbanyak pada multipara yaitu 98 orang (64,5\%).

Tabel 1. Distribusi persalinan letak sungsang berdasarkan paritas

\begin{tabular}{lcc}
\hline Paritas & $\mathrm{n}$ & $\%$ \\
\hline Primipara & 51 & 33,5 \\
Multipara & 98 & 64,5 \\
Grandemultipara & 3 & 2,0 \\
Jumlah & 152 & 100 \\
\hline
\end{tabular}

Tabel 2 menunjukkan bahwa persalinan letak sungsang paling banyak ditemukan pada pasien kelompok usia diatas 35 tahun yaitu 44 orang (28,9\%).

Tabel 3 menunjukkan bahwa pada usia kehamilan 37-40 minggu ditemukan paling banyak persalinan letak sungsang yaitu 119 orang $(78,3 \%)$.

Tabel 4 menunjukkan bahwa presentasi terbanyak ialah complete breech yaitu sebanyak 101 orang $(66,4 \%)$. 
Tabel 2. Distribusi persalinan letak sungsang berdasarkan usia ibu

\begin{tabular}{ccc}
\hline $\begin{array}{c}\text { Usia ibu } \\
\text { (tahun) }\end{array}$ & $\mathrm{n}$ & $\%$ \\
\hline$\leq 20$ & 14 & 9,2 \\
$21-25$ & 32 & 21,1 \\
$26-30$ & 31 & 20,4 \\
$31-34$ & 31 & 20,4 \\
$\geq 35$ & 44 & 28,9 \\
\hline Jumlah & 152 & 100 \\
\hline
\end{tabular}

Tabel 3. Distribusi persalinan letak sungsang berdasarkan usia kehamilan

\begin{tabular}{ccc}
\hline $\begin{array}{c}\text { Usia kehamilan } \\
\text { (minggu) }\end{array}$ & $\mathrm{n}$ & $\%$ \\
\hline$<37$ & 11 & 7,2 \\
$37-40$ & 119 & 78,3 \\
$\geq 41$ & 22 & 14,5 \\
Jumlah & 152 & 100 \\
\hline
\end{tabular}

Tabel 4. Distribusi persalinan letak sungsang berdasarkan jenis presentasi

\begin{tabular}{lcc}
\hline Jenis Presentasi & $\mathrm{n}$ & $\%$ \\
\hline Frank breech & 31 & 20,4 \\
Complete breech & 101 & 66,4 \\
Incomplete breech & 20 & 13,2 \\
Jumlah & 152 & 100 \\
\hline
\end{tabular}

Tabel 5 menunjukkan bahwa jenis pertolongan persalinan yang paling sering dilakukan pada letak sungsang yaitu persalinan perabdominal yaitu sebanyak 119 orang $(78,3 \%)$.

Tabel 5. Distribusi persalinan letak sungsang berdasarkan jenis persalinan

\begin{tabular}{ccc}
\hline Jenis persalinan & $\mathrm{n}$ & $\%$ \\
\hline Pervaginam & 33 & 21,7 \\
Perabdominal: & 119 & 78,3 \\
Oligohidramnion & 34 & 28,6 \\
KPD & 43 & 36,1 \\
Makrosomia & 18 & 15,1 \\
Hipertensi Kronik & 12 & 10,1 \\
Hamil tua & 2 & 1,7 \\
Kista & 10 & 8,4 \\
Jumlah & 152 & 100 \\
\hline
\end{tabular}

Tabel 6 menunjukkan bahwa berat badan lahir bayi letak sungsang terbanyak adalah 2500-3500 g yaitu sebanyak 99 orang $(65,1 \%)$.

Tabel 6. Distribusi persalinan letak sungsang berdasarkan berat badan lahir

\begin{tabular}{lcc}
\hline Berat badan lahir & $\mathrm{n}$ & $\%$ \\
\hline$<2500 \mathrm{~g}$ & 18 & 11,8 \\
$2500-3500 \mathrm{~g}$ & 99 & 65,1 \\
$>3500 \mathrm{~g}$ & 35 & 23,1 \\
Jumlah & 152 & 100 \\
\hline
\end{tabular}

Tabel 7 menunjukkan bahwa nilai apgar 46 terbanyak ditemukan pada persalinan letak sungsang yaitu 93 orang (61,2\%).

Tabel 7. Distribusi persalinan letak sungsang berdasarkan nilai apgar

\begin{tabular}{ccc}
\hline Nilai Apgar & $\mathrm{n}$ & $\%$ \\
\hline 0 & 1 & 0,6 \\
$1-3$ & 26 & 17,1 \\
$4-6$ & 93 & 61,2 \\
$7-9$ & 32 & 21,1 \\
Jumlah & 152 & 100 \\
\hline
\end{tabular}

\section{BAHASAN}

Berdasarkan distribusi menurut paritas (Tabel 1) didapatkan jumlah tertinggi pada multipara yaitu sebanyak 98 kasus (64,5\%), kemudian pada primipara sebanyak 51 kasus $(33,5 \%)$ dan yang terendah pada grandemultipara yaitu 3 kasus (2,0\%). Hal ini sesuai dengan teori yang menyatakan pada multipara kejadian letak sungsang lebih tinggi daripada primipara karena janin lebih mudah bergerak. ${ }^{12,13}$ Pada penelitian yang dilakukan Nurul $^{13}$ ditemukan juga angka kejadian tertinggi pada multipara yaitu sebesar 53 orang dari total sampel 102 (52,0\%).

Berdasarkan distribusi menurut usia ibu (Tabel 2) didapatkan jumlah tertinggi pada usia diatas 35 tahun yaitu sebanyak 44 kasus (28,9\%), diikuti oleh usia 21-25 tahun sebanyak 32 kasus $(21,1 \%)$, usia 2630 tahun sebanyak 31 kasus (20,4\%), usia 31-34 tahun sebanyak 31 kasus (20,4\%), dan yang terendah usia kurang dari 20 tahun yaitu 14 kasus (9,2\%). Hasil yang didapatkan ini berbeda dengan penelitian yang dilakukan Dengah ${ }^{14}$ yang menemukan 
kasus kelompok tertinggi pada usia 20-25 tahun yaitu sebanyak 23 orang (26,43\%).

Berdasarkan distribusi menurut usia kehamilan (Tabel 3) didapatkan jumlah tertinggi pada usia kehamilan 37-40 minggu yaitu sebanyak 119 kasus (78,3\%). Hasil penelitian ini ternyata tidak sejalan dengan teori yang menyatakan bahwa kejadian letak sungsang banyak terjadi pada usia kehamilan kurang bulan dan pada usia kehamilan cukup bulan biasanya ialah letak kepala. Hal ini juga ditemukan pada penelitian sebelumnya yang dilakukan Dengah $^{14}$ ditemukan kasus tertinggi pada usia kehamilan 37-41 minggu yaitu sebanyak 74 orang $(85,05 \%)$.

Berdasarkan distribusi menurut jenis presentasi didapatkan jumlah kasus tertinggi pada complete breech yaitu sebanyak 101 kasus (66,4\%). Hasil penelitian ini sesuai dengan teori bahwa angka tertinggi jenis presentasi pada persalinan letak sungsang ialah letak sungsang sempurna yakni $75 \%$ dan yang terendah letak sungsang tidak sempurna sebesar $25 \%$. Nurul ${ }^{13}$ juga menemukan hal yang sama, yaitu dari 102 sampel didapatkan sebanyak 68 kasus complete breech $(66,6 \%)$.

Berdasarkan distribusi menurut jenis persalinan (Tabel 5) didapatkan jumlah tertinggi pada persalinan perabdominal (operasi sesar) yaitu sebanyak 119 kasus (78,3\%). Menurut teori indikasi dilakukannya tindakan seksio antara lain ibu yang primi tua, bekas seksio sesaria, ada indikasi janin untuk mengakhiri persalinan (hipertensi, KPD), dan curiga panggul sempit. Hal ini juga didapatkan pada ibu kasus persalinan perabdominal di penelitian ini. Hasil serupa juga dilaporkan oleh penelitian sebelumnya yang dilakukan Dengah $^{14}$ yang mendapatkan jenis persalinan perabdominal sebanyak 48 kasus $(55,17 \%))^{4,14}$

Berdasarkan distribusi menurut berat badan lahir (Tabel 6) didapatkan jumlah tertinggi pada bayi 2500 - 3500 g yaitu sebanyak 99 kasus (65,1\%), diikuti pada bayi $>3500$ g sebanyak 35 kasus (23,1\%), sedangkan yang terendah pada bayi $<2500$ g yaitu 18 kasus (11,8\%). Pada penelitan sebelumnya yang dilakukan Dengah ${ }^{15}$ ditemukan jumlah tertinggi pada rentang berat badan lahir 2500 - 3000 g yaitu sebanyak 37 kasus (42,52\%).

Berdasarkan distribusi menurut nilai apgar (Tabel 7) didapatkan jumlah tertinggi pada nilai 4-6 yaitu sebanyak 93 kasus (61,2\%), kemudian pada nilai 1-3 sebanyak 26 kasus (17,1\%), pada nilai 7-9 sebanyak 32 kasus $(21,1 \%)$, sedangkan yang terendah pada nilai 0 yaitu 1 kasus $(0,6 \%)$. Hal ini berbeda dengan hasil yang didapatkan pada penelitian sebelumnya yang dilakukan Dengah $^{14}$ dimana ditemukan kasus tertinggi pada nilai apgar 7-10 yaitu sebanyak 76 kasus (87,35\%).

\section{SIMPULAN}

Jumlah persalinan letak sungsang di RSUP Prof. Dr. R. D. Kandou Manado yaitu sebanyak 152 kasus (2,2\%).

\section{SARAN}

Bagi peneliti selanjutnya, perlu diteliti lebih lanjut lagi factor-faktor lain yang berhubungan dengan persalinan letak sungsang.

\section{DAFTAR PUSTAKA}

1. Amru S. In: Rustam Mochtar Sinopsis Obstetri (3rd ed). Jakarta: ECG, 2011; p. 243-50.

2. Cunningham FG, Gant NF, Leveno KJ, Gilstrap III LC, Hauth JC, Wenstrom KD. In: Obstetri Williams (21st ed). Jakarta: ECG, 2004; p. 55981.

3. Rustam. In: Sinopsis Obstetri Jilid 1. Jakarta: EGC, 2005.

4. Prawirohardjo S. In: Ilmu Kebidanan. Jakarta: Yayasan Bina Pustaka Sarwono Prawirohardjo, 2008; p. 609-11.

5. Leveno KJ, Cunningham FG, Gant NF, Alexander JM, Bloom SL, Casey BM, et al. Pelahiran Bokong. In: William Obstetri Panduan Ringkas (21st ed). Jakarta: ECG, 2009; p. 22948.

6. Manuaba Ida BG. In: Operasi Kebidanan Kandungan dan Keluarga Berencana Untuk Dokter Umum. Jakarta: ECG, 
1995; p. 174-201.

7. Manuaba Ida BG. In: Ilmu Kebidanan Penyakit Kandungan. Jakarta: ECG, 1998.

8. Joewono BN. Angka kematian ibu, 228/100.000 kelahiran hidup. 2012. [cited 10 Juli 2015]. Available from: http://www.lipsus.kompas.com/hiday atdidik/read/2012/01/31/22093816/A ngka.Kematian.Ibu.228/100.000.Kela hiran.Hidup.

9. Manuaba Ida BG. In: Kapita Selekta Penatalaksanaan Rutin Obstetri, Ginekologi,dan KB. Jakarta: ECG, 2001 p. 237-41.

10. Kehamilan letak sungsang. 2011. [cited: 23 Sept 2014]. Available from: http://doktermaya.wordpress.com/201 1/11/30/kehamilan-letak-sungsang/.

11. Sastrawinata S, Martaadisoebrata $D$, Wirakusumah FF. In: Obstetri Patologi Ilmu Kesehatan Reproduksi. Jakarta: EGC, 2003; p. 134-45.

12. Cunningham FG. In: Obstetri Williams (21st ed). Jakarta: EGC, 2005; p. 568.

13. Nurul KS. Hubungan tingkat paritas dan kejadian letak sungsang pada ibu bersalin di RSUD dr. R. Koesma Tuban Tahun 2008 [Skripsi]. Tuban: STIKES NU Tuban; 2008.

14. Dengah S. Gambaran persalinan letak sungsang di BLU RSUP Prof. dr. R. D. Kandou Manado periode 1 Januari 2010 - 31 Desember 2011 [Skripsi]. Manado: FK Unsrat; 2011. 